\title{
Bovine inositol monophosphatase
}

\section{Modification, identification and mutagenesis of reactive cysteine residues}

\author{
Michael R. KNOWLES, ${ }^{*}$ Nicholas GEE, ${ }^{*}$ George McALLISTER, ${ }^{*}$ C. Ian RAGAN, ${ }^{*} \ddagger$ Peter J. GREASLEY $\dagger$ and \\ Michael G. GORE $\dagger$ \\ ${ }^{*}$ Neuroscience Research Centre, Merck Sharp and Dohme, Terlings Park, Eastwick Road, Harlow, Essex CM20 2QR, U.K., \\ and $†$ Department of Biochemistry, Centre of Molecular Recognition, School of Biological Sciences, University of Southampton, \\ Bassett Crescent East, Southampton SO9 3TU, U.K.
}

\begin{abstract}
1. Bovine inositol monophosphatase reacts with thiol reagents such as 5,5'-dithiobis-(2-nitrobenzoic acid) (DTNB), $N$ ethylmaleimide (NEM) and iodoacetic acid (IAA). 2. Modification by NEM results in nearly total loss of enzyme activity, whereas modification by IAA causes a slight increase in activity. 3. The loss of activity caused by NEM can be prevented by the inclusion of Ins $1 P$, or better Ins $1 P$ and $\mathrm{LiCl}$ in the reaction mixture. 4. Two equivalents of $p$-nitrothiobenzoate $\left(\mathrm{NTB}^{2-}\right)$ are released from the native enzyme on reaction with DTNB, and six equivalents of $\mathrm{NTB}^{2-}$ are released from the SDS-denatured enzyme, suggesting that none of the six cysteine residues per molecule of enzyme is involved in intraor inter-molecular disulphide bridges. 5. Both NEM and IAA react with two cysteine residues (residues 141 and 184 in the sequence) in a mutually exclusive manner. 6 . NEM also reacts stoichiometrically with residue 218 . 7 . The NEM-induced loss of enzyme activity is accompanied by a $15 \%$ decrease in protein fluorescence. 8 . A mutant of the enzyme which has an Ala-218 replacement for Cys-218 has full activity and is not sensitive to NEM, showing that the modification of this cysteine by NEM causes inhibition of the native protein by steric effects and that Cys-218 is not essential for activity.
\end{abstract}

\section{INTRODUCTION}

Extracellular signals are converted into intracellular events in the process of communication between cells. One of these signal pathways utilizes the receptor-mediated action of phospholipase C on phosphatidylinositol 4,5-bisphosphate, generating the secondary messengers 1,2-diacylglycerol and inositol 1,4,5-trisphosphate (for reviews see [1-3]). The latter molecule mobilizes intracellular $\mathrm{Ca}^{2+}$ and can be metabolized to generate a number of different inositol phosphates, including Ins $1 P$, Ins $3 P$ and Ins4 $P$, all of which are substrates [4] for the enzyme inositol monophosphatase (EC 3.1.3.25). Additionally, inositol is produced by synthesis de novo when glucose 6-phosphate is metabolized to Ins $3 P$ [5]. Since transfer of dietary inositol across the blood-brain barrier is slow, brain tissue is dependent on the enzyme inositol monophosphatase for the production of inositol. Inositol monophosphatase is a dimer of identical subunits each of $M_{\mathrm{r}} 30000$ [4]. It has an absolute requirement for $\mathrm{Mg}^{2+}$, but is inhibited by high concentrations of $\mathrm{Mg}^{2+}$ or by $\mathrm{Li}^{+}[4,6]$. It has been proposed that $\mathrm{Li}^{+}$can trap a phosphoenzyme intermediate, preventing subsequent nucleophilic attack by water [7]. This mechanism accounts for the observation that $\mathrm{Li}^{+}$inhibits uncompetitively with substrate [6], a property which has been implicated in the efficacy of $\mathrm{Li}^{+}$in the treatment of manic depression $[4,8]$. Despite the cloning of cDNA for bovine inositol monophosphatase [9], little is yet known about the residues involved in substrate binding and catalysis, although recent work [10] suggests that groups with $\mathrm{p} K_{\mathrm{a}}$ values of $6.4,8.3$ and 8.9 may be involved in the inhibition of the enzyme by $\mathrm{Li}^{+}$and $\mathrm{Mg}^{2+}$. The $\mathrm{p} K_{\mathrm{a}}$ of 8.3 is very similar to that expected for the thiolate group of cysteine, and may imply a role for cysteine in the binding of the inhibitory metal ion.

Thiol groups in proteins have been widely studied by the process of chemical modification $[11,12]$. Suitable reagents for this use include $N$-ethylmaleimide (NEM) [13], 5,5'-dithiobis-(2nitrobenzoic acid) (Ellman's reagent; DTNB) [14] and the haloacetates [15]. In this paper we describe the inactivation of the enzyme by these reagents and have identified the sites of modification. The results suggest that there are several cysteine residues in inositol monophosphatase available for modification and that one of these is located at or near the active site of the enzyme.

\section{MATERIALS AND METHODS}

\section{Materials}

The growth of bacterial cultures and the subsequent extraction and purification of inositol monophosphatase is described elsewhere [16]. All reagents were purchased from BDH, Poole, Dorset, U.K. Radionucleotides were purchased from Amersham International, Amersham, Bucks, U.K. Optiphase Hi-safe 3 scintillant was obtained from LKB, Croydon, Surrey, U.K. DLInositol 1-phosphate was synthesized as described by Billington et al. [17], and the inhibitor (1S)-phosphoryloxy-(2R,4S)-dihydroxycyclohexane as described by Baker et al. [18].

\section{Enzyme activity}

Inositol monophosphatase activity, $V_{\max }$ and the $K_{\mathrm{m}}$ for substrate were determined by the radiochemical assay previously described [19], by the method of De Groot et al. [20] or the discontinuous assay of Lanzetta et al. [21].

\section{Protein concentration}

The concentration of inositol monophosphatase was determined by the method of Bradford [22].

\section{Modification of inositol monophosphatase by thiol reagents \\ Stock solutions $100 \mathrm{mM}$ of DTNB, NEM and iodoacetic acid}

\footnotetext{
Abbreviations used: DTNB, 5,5'-dithiobis-(2-nitrobenzoic acid); $\mathrm{NTB}^{2-}, p$-nitrothiobenzoate; NEM, $N$-ethylmaleimide; IAA, iodoacetic acid; TFA, trifluoroacetic acid; PTH, phenylthiohydantoin.

$\ddagger$ To whom correspondence should be addressed.
} 
(IAA) were prepared in $1.025 \mathrm{M}$-Tris $/ \mathrm{HCl}(\mathrm{pH} 8.0) / 125 \mathrm{~mm}$ $\mathrm{KCl} / 1.5 \mathrm{~mm}-\mathrm{MgCl}_{2}$. Serial dilutions were made with the same buffer. Then $0.001-10 \mathrm{~mm}$ of each reagent was incubated with $20 \mu \mathrm{l}$ of $3.3 \mu \mathrm{M}$ enzyme $\left(M_{\mathrm{r}} 30055\right)$ at $21^{\circ} \mathrm{C}$ for $30 \mathrm{~min}$ in a final volume of $200 \mu$ l containing $50 \mathrm{~mm}-\mathrm{Tris} / \mathrm{HCl}$ (pH 8.0), $250 \mathrm{~mm}$ $\mathrm{KCl}$ and $3 \mathrm{~mm}-\mathrm{MgCl}_{2}$.

\section{Ligand protection experiments}

To $100 \mu$ l of inositol monophosphatase $(0.2 \mathrm{mg} / \mathrm{ml})$ was added $20 \mu \mathrm{l}$ of $100 \mathrm{~mm}$-EGTA, $20 \mu \mathrm{l}$ of $10 \mathrm{~mm}-1,10$-phenanthroline, $60 \mu \mathrm{l}$ of $50 \mathrm{~mm}-\mathrm{Tris} / \mathrm{HCl}(\mathrm{pH} 8.0) / 250 \mathrm{~mm}-\mathrm{KCl} / 3 \mathrm{~mm}-\mathrm{MgCl}_{2}$ and $20 \mu \mathrm{l}$ of $100 \mathrm{~mm}-\mathrm{NEM}$. A $20 \mu \mathrm{l}$ portion of each ligand was included in the reaction mixture, with a suitable decrease in the amount of buffer used. The ligands used were $100 \mathrm{~mm}-\mathrm{LiCl}$, $100 \mathrm{~mm}-\mathrm{NaCl}, 100 \mathrm{~mm}$-Ins $1 P, 100 \mathrm{~mm}$-phosphate $\left[\mathrm{K}_{2} \mathrm{HPO}_{4}\right.$ in $50 \mathrm{~mm}-\mathrm{Tris} / \mathrm{HCl}$ (pH 8.0)] and $10 \mathrm{~mm}-(1 S)$-phosphoryloxy$(2 R, 4 S)$-dihydroxycyclohexane. After $30 \mathrm{~min}$ incubation at $21{ }^{\circ} \mathrm{C}$, each reaction was terminated by passage down a Sephadex G-25 column equilibrated with $150 \mathrm{~mm}-\mathrm{NaCl}$ and $50 \mathrm{~mm}-$ Tris $/ \mathrm{HCl}(\mathrm{pH} 8.0)$. The eluted enzyme was assayed for activity as described in [19].

\section{Modification of inositol monophosphatase by [ $\left.{ }^{3} \mathrm{H}\right]$ IAA}

Labelling studies of inositol monophosphatase with IAA were carried out at $37^{\circ} \mathrm{C}$ by addition of $5.3 \mathrm{~mm}-\left[{ }^{3} \mathrm{H}\right] \mathrm{IAA}$ (sp. radioactivity $\left.9.6 \times 10^{6} \mathrm{~d} . \mathrm{p} . \mathrm{m} . / \mu \mathrm{mol}\right)$ to $5 \mathrm{ml}$ of $6 \mu \mathrm{M}$ inositol monophosphatase dissolved in $0.1 \mathrm{M}-\mathrm{Tris} / \mathrm{HCl}, \mathrm{pH} 8.0$, for up to $90 \mathrm{~min}$. At various times a $0.5 \mathrm{ml}$ sample was taken, the reaction was terminated by the addition of excess 2-mercaptoethanol, and the sample was then subsequently dialysed against $2 \times 5$ litres of $50 \mathrm{~mm}$-Tris/ $\mathrm{HCl}$ buffer, $\mathrm{pH} 8.0$, at $4{ }^{\circ} \mathrm{C}$. The stoichiometry of incorporation was assessed by liquid-scintillation counting in Optiphase scintillant (LKB) in a Philips 4700 scintillation counter.

\section{Modification of inositol monophosphatase by IAA for the isolation of labelled peptides}

To $10 \mathrm{mg}$ of inositol monophosphatase was added $5 \mathrm{mg}$ of $\left[{ }^{3} \mathrm{H}\right]$ IAA (sp. radioactivity $9.6 \times 10^{6}$ d.p.m. $/ \mu \mathrm{mol}$ ) in $8 \mathrm{ml}$ of $50 \mathrm{~mm}$-Tris $/ \mathrm{HCl}$ buffer, $\mathrm{pH} 8.0$. The reaction was allowed to proceed for $16 \mathrm{~h}$ at $37^{\circ} \mathrm{C}$, and the sample was then dialysed against $2 \times 5$ litres of the same buffer and then $1 \times 5$ litres of water before being freeze-dried. The freeze-dried protein was resuspended in $2 \mathrm{ml}$ of $0.1 \mathrm{M}$-Tris/ $\mathrm{HCl}$ buffer, $\mathrm{pH} 8.0$, containing $5 \%$ $(\mathrm{v} / \mathrm{v})$ acetonitrile, and a small sample was taken for measurement of the radioactivity incorporated. Trypsin was added $(0.5 \mathrm{mg})$ and the mixture incubated at $37^{\circ} \mathrm{C}$ for $16 \mathrm{~h}$. A second proteolytic step was then taken by adding Staphylococcus aureus $\mathrm{V} 8$ protease $(0.1 \mathrm{mg})$, and the mixture incubated again at $37^{\circ} \mathrm{C}$ for a further $6 \mathrm{~h}$. A small sample $(40 \mu \mathrm{l})$ was then taken, centrifuged in a Microfuge, and the supernatant was taken for measurement of the radiolabel. The precipitate was then redissolved in $40 \mu \mathrm{l}$ of $10 \%(\mathrm{v} / \mathrm{v}) \mathrm{SDS}$, and this was again taken for measurement of the amount of radiolabelled peptides or undigested protein, which were insoluble in water alone. Approx. $97 \%$ of the radioactivity was found in the water-soluble fraction, and this was therefore taken for the isolation of the labelled peptides by reverse-phase h.p.l.c.

\section{Modification of inositol monophosphatase by $\left[{ }^{14} \mathrm{C}\right] \mathrm{NEM}$}

Labelling studies of inositol monophosphatase with NEM were carried out at $21^{\circ} \mathrm{C}$ by the addition of $1 \mathrm{~mm}-\left[{ }^{14} \mathrm{C}\right] \mathrm{NEM}$ (sp. radioactivity $15.4 \times 10^{6}$ d.p.m. $/ \mu \mathrm{mol}$ ) to $5 \mathrm{ml}$ of $6 \mu \mathrm{M}$-inositol monophosphatase dissolved in $0.1 \mathrm{M}-\mathrm{Tris} / \mathrm{HCl}, \mathrm{pH} 8.0$, for up to $30 \mathrm{~min}$. The samples were then treated in the same way as those treated with IAA as described above.

\section{Modification of inositol monophosphatase by NEM for the isolation of labelled peptides}

(a) In the absence of substrates. Inositol monophosphatase $(500 \mu \mathrm{l} ; 2 \mathrm{mg} / \mathrm{ml})$ was added to a reaction mixture of $10 \mathrm{~mm}$ $\left[{ }^{14} \mathrm{C}\right] \mathrm{NEM}, 2.7 \mathrm{mM}-\mathrm{MgCl}_{2}$ and $150 \mathrm{~mm}-\mathrm{NaCl}$ in $50 \mathrm{~mm}-\mathrm{Tris} / \mathrm{HCl}$ buffer, $\mathrm{pH}$ 8.0. The reaction was initiated by addition of inositol monophosphatase and allowed to continue for $5 \mathrm{~min}$ at $21^{\circ} \mathrm{C}$. The reaction was terminated by passing the reaction mixture down a Sephadex G-25 column pre-equilibrated with $150 \mathrm{~mm}$ $\mathrm{NaCl}$ in $50 \mathrm{~mm}$-Tris/ $\mathrm{HCl}$ buffer, $\mathrm{pH} \mathrm{8.0.} \mathrm{The} \mathrm{column} \mathrm{was} \mathrm{then}$ washed in the same buffer and $0.5 \mathrm{ml}$ samples were collected. A $10 \mu \mathrm{l}$ portion of each fraction was added to $10 \mathrm{ml}$ of water $/ 10 \mathrm{ml}$ of scintillation fluid and the radioactivity detected in an automated liquid-scintillation counter. Fractions containing both protein (determined by $A_{280}$ ) and radioactivity were pooled, and a $10 \mu \mathrm{l}$ sample was taken from the pooled material in order to assess the stoichiometry of incorporation. Protein concentration was determined by the method of Bradford [22].

(b) In the presence of substrates. The method was as above, except that the reaction mixture also contained $10 \mathrm{~mm}$-Ins $1 P$ and $25 \mathrm{mM}^{-\mathrm{Li}^{+}}$as $\mathrm{LiCl}$.

\section{Reductive carboxymethylation and proteolytic digestion of the $\left[{ }^{14}\right.$ C]NEM-labelled inositol monophosphatase}

To each modified sample was added guanidinium chloride to a final concentration of $6 \mathrm{M}, 2$-mercaptoethanol to $0.72 \mathrm{M}$ and Tris $/ \mathrm{HCl}(\mathrm{pH} 8.5)$ to a final concentration of $0.1 \mathrm{M}$. The samples were then flushed with $\mathrm{N}_{2}$ and incubated for $16 \mathrm{~h}$ at $40^{\circ} \mathrm{C}$. Then $520 \mathrm{mg}$ of IAA was added and the pH maintained at 8.5 by addition of $5 \mathrm{M}-\mathrm{NaOH}$. The samples were then flushed with $\mathrm{N}_{2}$ and incubated in the dark for $60 \mathrm{~min}$ at $21^{\circ} \mathrm{C}$. An excess of 2mercaptoethanol was then added, and the samples were dialysed

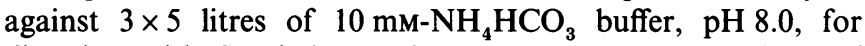
digestion with Staphylococcal V8 protease, or $3 \times 5$ litres of $50 \mathrm{~mm}-\mathrm{Tris} / \mathrm{HCl}, \mathrm{pH} 8.0$, for digestion by tosylphenylalanylchloromethane-treated trypsin. In either case dialysis was carried out at $4{ }^{\circ} \mathrm{C}$. The samples were then freeze-dried.

Digestion with $\mathrm{V8}$ protease. The freeze-dried samples were

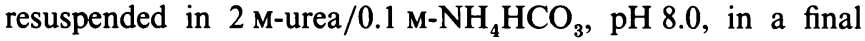
volume equal to $\frac{1}{10}$ of the volume before freeze-drying. V8 protease was added $(2 \%$ of the wt. of inositol monophosphatase protein) and the digestion incubated at $21^{\circ} \mathrm{C}$ for $16 \mathrm{~h}$. A further $1 \%(\mathrm{w} / \mathrm{w})$ of the protease was then added and the mixture incubated for a further $7 \mathrm{~h}$.

Digestion with trypsin. The samples labelled with $\left[{ }^{14} \mathrm{C}\right] \mathrm{NEM}$ were resuspended in aq. $10 \%(\mathrm{v} / \mathrm{v})$ acetonitrile, trypsin was added ( $5 \%$ of the wt. of inositol monophosphatase protein), and the digestion was incubated at $37^{\circ} \mathrm{C}$ for $16 \mathrm{~h}$.

\section{Purification of $\left[{ }^{14} \mathrm{C}\right]$ NEM labelled peptides by h.p.l.c.}

(a) Active-site peptides (peptides which do not appear when modification by reagent is carried out in the presence of $\operatorname{Ins} 1 P$ and $\mathbf{L i}^{+}$). Digested samples were centrifuged for $5 \mathrm{~min}$ in a Microfuge to separate any insoluble peptides, then both supernatant and pellet were assayed for radioactivity. All of the radiolabel appeared in the supernatant, which was taken for h.p.l.c. analysis. Peptides generated by proteolysis of inositol monophosphatase labelled by NEM in the presence or absence of substrate were applied to a Synchropak cation-exchange column (4.6 $\mathrm{mm} \times 25 \mathrm{~mm}$; Synchrom, Lafayette, IN, U.S.A.) with a flow rate of $1 \mathrm{ml} / \mathrm{min}$ and a solvent gradient of (A) $5 \mathrm{mM}-\mathrm{K}_{2} \mathrm{HPO}_{4}$, pH 3.0, and (B) $5 \mathrm{~mm}-\mathrm{K}_{2} \mathrm{HPO}_{4}$ containing $1 \mathrm{M}-\mathrm{NaCl}, \mathrm{pH} 3.0$. Buffer $\mathrm{A}$ was applied for $8 \mathrm{~min}$ and was followed by a linear gradient of $0-100 \%$ B over $50 \mathrm{~min}$. Peptide elution was monitored at $214 \mathrm{~nm}$, and ${ }^{14} \mathrm{C}$ was monitored by scintillation counting 
as above. Further purification was achieved by the application of samples to a reverse-phase $C_{18}$ column with a gradient composed of buffer (A), $0.1 \%(\mathrm{v} / \mathrm{v})$ trifluoroacetic acid (TFA) in water, and (B), $0.1 \%$ TFA in acetonitrile. The column was equilibrated in $95 \% \mathrm{~A} / 5 \% \mathrm{~B}$, and the sample was injected and the same solvents were applied for $5 \mathrm{~min}$. A gradient of $5 \%-18 \%$ B over 90 min was applied, followed by a gradient of $18-40 \%$ B over the next $120 \mathrm{~min}$. Finally the concentration of $\mathrm{B}$ was increased to $100 \%$ over a further $90 \mathrm{~min}$.

(b) Peptides labelled by $\left[{ }^{14} \mathrm{C}\right] \mathrm{NEM}$ in the presence or absence of Ins1 $P$ and $\mathbf{L i}^{+}$. A $50 \mu$ l portion of tryptic/V8-digested inositol monophosphatase was run on an $\mathrm{C}_{8}$ reverse-phase column attached to a Gilson 302 gradient h.p.l.c. system. The peptides were eluted from the column by a gradient of $0.1 \%$ TFA in water and $0.1 \%$ TFA in acetonitrile and detected by their $A_{235}$ (for details of the gradient see Fig. 4); $10 \mu$ l samples from each eluted peptide were taken and counted for radioactivity as above. Radiolabelled peptides were dried in vacuo and re-applied to a reverse-phase $C_{18}$ column $(4.6 \mathrm{~mm} \times 25 \mathrm{~mm})$ equilibrated in the same solvent system. Isocratic elution was carried out with a percentage of acetonitrile in $0.1 \%$ which was 10 less than the percentage used to elute that peak from the $\mathrm{C}_{\underline{8}}$ column.

Purification of the $\left[{ }^{3} \mathbf{H}\right]$ carboxymethylated peptides by h.p.l.c.

This was as described in (b) above.

\section{Protein sequencing}

The sequence of the amino acids in each peptide was determined with an Applied Biosystems 477A sequencer with an on-line 120A h.p.l.c. for the identification of the amino acid phenylthiohydantoin (PTH) released at each cycle.

\section{Fluorescence studies}

Changes in protein fluorescence after modification by $1 \mathrm{~mm}$ NEM were monitored with a Perkin-Elmer 650S fluorescence detector. All modifications were carried out in $50 \mathrm{~mm}-\mathrm{Tris} / \mathrm{HCl}$ (pH 8.0)/250 mM-KCl/3 mM- $\mathrm{MgCl}_{2}$ at $21^{\circ} \mathrm{C}$ in a final volume of $1 \mathrm{ml}$. Each incubation contained $0.1 \mathrm{mg}$ of inositol monophosphatase (per $\mathrm{ml}$ ), and the ligands were included from stocks detailed above, with suitable decreases in the amount of buffer in each reaction mixture to maintain volume.

\section{Site-directed mutagenesis}

Oligonucleotide-directed mutagenesis was carried out by the method of Kunkel and co-workers [23,24]. The plasmid used was the pRSET vector containing the gene coding for the bovine brain inositol monophosphatase [9]. The oligonucleotide 5'AACATCCCAGGCGTGGATCCC-3' was synthesized on an Applied Biosystems model 380 DNA synthesizer and used to generate a mutant in which residue 218 is changed from cysteine to alanine. The sequence of the mutant was determined by the dideoxy chain-termination method [25].

\section{RESULTS}

\section{Inhibition of inositol monophosphatase by cysteine-modifying reagents}

Purified bovine inositol monophosphatase was incubated with various concentrations of thiol-modifying reagents for $30 \mathrm{~min}$ at $\mathrm{pH} 8.0,21^{\circ} \mathrm{C}$, and subsequently assayed for activity. Fig. 1 shows that both DTNB and NEM cause high loss of activity in this period when used at concentrations between 0.01 and $0.1 \mathrm{mM}$. Modification by $0.1 \mathrm{mM}-\mathrm{NEM}$ or -DTNB resulted in a $94 \%$ or $80 \%$ decrease in the original activity respectively. Interestingly, incubation with chloro-, bromo- or iodo-acetic acid had no effect on enzyme activity at low concentrations $(<1 \mathrm{~mm})$, but resulted in a $20 \%$ increase in enzyme activity at higher levels (only the data obtained with IAA are shown in Fig. 1). These results suggest that there is one (or more) residue(s), most probably cysteine, in the enzyme available for modification by these reagents.

\section{Determination of the number of available cysteine residues}

The number of cysteine residues available for modification was estimated by treating $6 \mu \mathrm{M}$ enzyme $\left(M_{\mathrm{r}} 30055\right)$ in $50 \mathrm{~mm}$ Tris/ $\mathrm{HCl}$ buffer, $\mathrm{pH} 8.0$ (also containing $150 \mathrm{~mm}-\mathrm{NaCl}$ ), with $0.5 \mathrm{~mm}$-DTNB and measuring the $A_{412}\left(\epsilon_{412}=13600 \mathrm{M}^{-1} \cdot \mathrm{cm}^{-1}\right)$. With native enzyme, $1.8-1.95$ residues were modified per monomeric unit, although the protein sequence derived from the gene sequence shows that there are six cysteine residues in the protein [9]. However, the number of cysteine residues available for

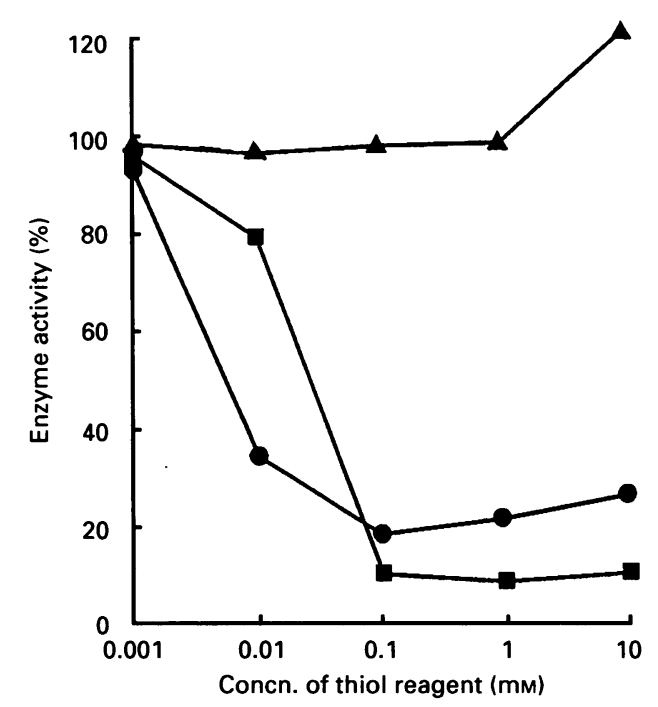

Fig. 1. Inactivation of bovine inositol monophosphatase by thiol reagents

Portions $(1 \mathrm{ml})$ of $3.3 \mu \mathrm{M}$ enzyme $\left(M_{\mathrm{r}} 30055\right)$ in $50 \mathrm{~mm}-\mathrm{Tris} / \mathrm{HCl}$ buffer, $\mathrm{pH} 8.0$, also containing $150 \mathrm{mM}-\mathrm{KCl}$ and $3 \mathrm{mM}-\mathrm{MgCl}_{2}$, were incubated at $21^{\circ} \mathrm{C}$ with various concentrations of DTNB (O), NEM ( $\mathbf{\square})$ or IAA (A) for $30 \mathrm{~min}$ before a sample was taken and assayed for activity as described in the Materials and methods section.

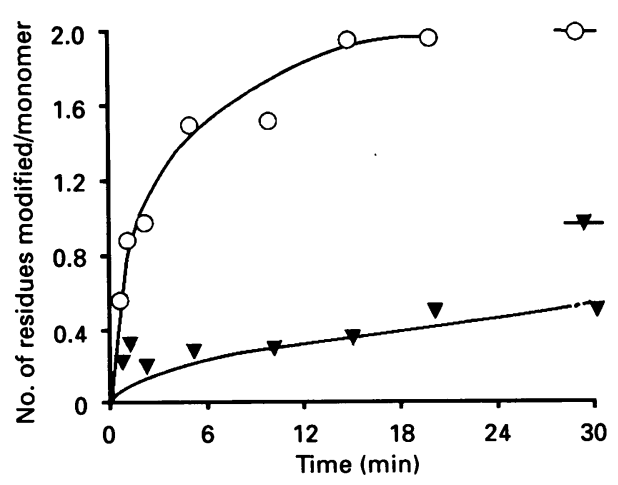

Fig. 2. Modification of inositol monophosphatase by $\left[{ }^{14} \mathrm{C}\right] \mathrm{NEM}$ or $\left[{ }^{3} \mathrm{H}\right] \mathrm{IAA}$

Native enzyme ( $6 \mu \mathrm{M}$ in $0.1 \mathrm{M}$-Tris/ $\mathrm{HCl}$ buffer, $\mathrm{pH} 8.0$ at $\left.21^{\circ} \mathrm{C}\right)$ was incubated with $1 \mathrm{mM}-\left[{ }^{14} \mathrm{C}\right] \mathrm{NEM}$ (sp. radioactivity $15.4 \times 10^{6} \mathrm{~d}$.p.m./ $\mu \mathrm{mol}$ ) (O) or $5.3 \mathrm{mM}-\left[{ }^{3} \mathrm{H}\right] \mathrm{IAA}$ (sp. radioactivity $9.6 \times 10^{6}$ d.p.m./ $\mu \mathrm{mol})(\boldsymbol{\nabla})$ at $21^{\circ} \mathrm{C}$, and the number of residues modified by either reagent was determined after exhaustive dialysis by liquidscintillation counting. 
Table 1. Loss of enzyme activity on reaction with NEM in the presence of various ligands

A $1 \mathrm{ml}$ portion of $3.3 \mu \mathrm{M}$ enzyme was incubated at $\mathrm{pH} 8.0,21^{\circ} \mathrm{C}$, for $30 \mathrm{~min}$ with $1 \mathrm{mM}-\mathrm{NEM}$ in the presence of buffer $(\mathrm{A}), 10 \mathrm{mM}-\mathrm{LiCl}$ (B), $10 \mathrm{~mm}$-phosphate (C), $10 \mathrm{~mm}$-Ins $1 P(\mathrm{D}), 10 \mathrm{~mm}$-Ins $1 P+10 \mathrm{~mm}-$ $\mathrm{LiCl}(\mathrm{E})$ or $1 \mathrm{~mm}$-(1S)-phosphoryloxy-(2R,4S)-dihydroxycyclohexane $(\mathrm{F})$.

\begin{tabular}{cc} 
Protecting agent & Enzyme activity remaining \\
\hline A & $30.3 \pm 1.8(n=3)$ \\
B & $44.5 \pm 0.5(n=2)$ \\
C & $30.5 \pm 5.5(n=2)$ \\
D & 75.0 \\
E & $91.3 \pm 4.3(n=3)$ \\
F & 95
\end{tabular}

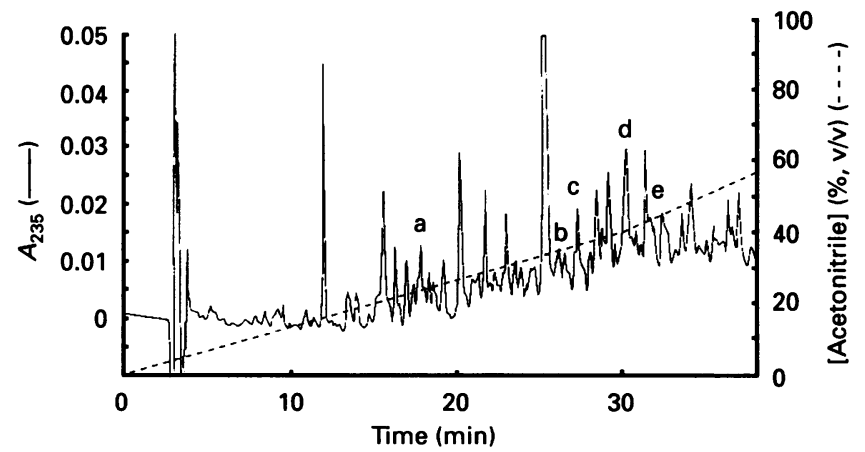

Fig. 3. Elution profile of tryptic/V8 peptides from $\left[{ }^{3} \mathrm{H}\right]$ carboxymethylated inositol monophosphatase on a $\mathrm{C}_{\mathbf{8}}$ reverse-phase column

Reverse-phase h.p.l.c. separation of peptides was performed on $\mathrm{C}_{8}$ column with a solvent gradient formed from $0.1 \%$ TFA in water and $0.1 \%$ TFA in acetonitrile. The flow rate was $1 \mathrm{ml} / \mathrm{min}$, and the gradient was run from 0 to $40 \%$ acetonitrile over $30 \mathrm{~min}$ and then to $60 \%$ over a further $10 \mathrm{~min}$. The Figure shows the elution profile $\left(A_{235}\right)$ obtained when $200 \mu$ l of $\left[{ }^{3} \mathrm{H}\right]$ IAA-modified inositol monophosphatase digest is applied and the peptides resolved. Peaks $a-e$ contained ${ }^{3} \mathrm{H}$-labelled peptides.

modification in the enzyme increased in the presence of $0.1 \%$ SDS from approx. 2 to 6 per monomer. Thus it can be concluded that only two residues or equivalents per monomer are accessible for modification in the native enzyme, and that all six become available upon non-reductive denaturation by SDS, implying that there are no intra- or inter-molecular disulphide bridges in the enzyme.

Fig. 2 demonstrates clearly that both the specificity and reactivity of the enzyme with IAA and NEM are different. Incubation of the enzyme with $5.3 \mathrm{~mm}-\left[{ }^{3} \mathrm{H}\right] \mathrm{IAA}$ (sp. radioactivity $=9.6 \times 10^{6}$ d.p.m. $\left./ \mu \mathrm{mol}\right)$ at $\mathrm{pH} 8.0$ leads to the incorporation of $0.86 \mathrm{~mol}$ equivalent of label after $90 \mathrm{~min}$, whereas a similar incubation in the presence of $1 \mathrm{mM}-\left[{ }^{14} \mathrm{C}\right] \mathrm{NEM}$ leads to a more rapid incorporation of $2.0 \mathrm{~mol}$ equivalent of label in 20 min (for exact conditions see the Materials and methods section). It is the modification of the second residue or equivalent by NEM which results in the large decrease in enzyme activity, suggesting that it is at or near the active site of inositol monophosphatase.

\section{Substrate protection from modification by thiol reagents}

To determine the possible involvement of this cysteine residue in enzyme/substrate interactions, we examined the ability of various ligands of the enzyme (e.g. Ins1 $\left.P, P_{1}\right)$ to protect against modification of the enzyme by NEM. The presence of $10 \mathrm{mM}$ $\mathrm{NaCl}, 10 \mathrm{~mm}-\mathrm{LiCl}$ or $10 \mathrm{~mm}$-phosphate failed to alter significantly the amount of activity lost after a 30 min incubation with $1 \mathrm{mM}$-NEM (Table 1), in contrast with the high level of protection afforded by the presence of $10 \mathrm{mM}$-Ins $1 P$, its presence resulting in only $25 \%$ decrease in enzyme activity. This protection by substrate was less than that found when $10 \mathrm{mM}-\mathrm{LiCl}$ was also included in the reaction mixture or when $1 \mathrm{mM}$ of the inhibitor (1S)-phosphoryloxy-(2R,4S)-dihydroxycyclohexane $\left(K_{\mathrm{d}}=1 \mu \mathrm{M}\right)$ [18] was used (Table 1). The increased protection from inactivation shown by substrate in the presence of $\mathrm{Li}^{+}$could be a result of formation of a stable $\mathrm{E}-\mathbf{P} \cdot \mathrm{Li}^{+}$complex [7], or simply because it prevents hydrolysis of the substrate. The observation that the substrate analogue gave full protection suggests that turnover is not needed and that $\mathrm{E} \cdot \mathrm{S}$ (or $\mathrm{E} \cdot \mathrm{I})$ is the protected species.

It therefore appears that the residue modified by NEM is not at or close to the phosphate-binding site, but within a region of the active site where its modification may prevent substrate binding.

\section{Identification of residues modified by $\left[{ }^{14} \mathrm{C}\right] \mathrm{NEM}$ and $\left[{ }^{3} \mathrm{H}\right] \mathrm{IAA}$}

Alkylation of the enzyme by IAA does not lead to a decrease in enzyme activity; in fact a small increase of activity of approx. $20 \%$ is consistently noted. Fig. 3 is an elution profile obtained when a sample of a V8-protein/trypsin double digest (see the Materials and methods section) of $\left[{ }^{3} \mathrm{H}\right] \mathrm{IAA}-\mathrm{modified} \mathrm{enzyme}$ was subjected to reverse-phase chromatography on a $C_{8}$ column (see Fig. 3 legend for details) and shows that the radioactivity was distributed between five peaks ( $a-e$; see Table 2$)$. These were collected and dried in vacuo and subjected to further purification on a $C_{18}$ reverse-phase system (see the Materials and methods section). Each peak ( $a$ to $e$ ) was resolved by this technique to yield single radiolabelled peptides. The final yield and sequence of each peptide is given in Table 2. Peak $a$ contained $34 \%$ of the radiolabel, and a PTH-carboxymethylcysteine peak was eluted after four cycles of the Edman degradation, corresponding to Cys-141. Peaks $b, d$ and $e$ collectively accounted for $57 \%$ of the radiolabel incorporated by carboxymethylation and were shown to be derivatives of the same tryptic peptides all containing Cys184. Peak $c$, containing $9 \%$ of the radiolabel, was shown to be a peptide representing residues $60-70$ in the linear sequence of the protein. This peptide contains no cysteine residues, and the radioactivity associated with this peptide was inferred to be due to carboxymethylation of His-65, since at this cycle of the Edman degradation no peak was detected at the standard elution time for PTH-histidine.

The stoichiometry of incorporation of NEM is $2 \mathrm{~mol} / \mathrm{mol}$ of inositol monophosphatase. The identification of the residue(s) reactive to NEM but not at or near to the active site was investigated by modification of the enzyme by $10 \mathrm{mM}-\left[{ }^{14} \mathrm{C}\right] \mathrm{NEM}$ in the presence of the substrate and $\mathrm{Li}^{+}$, under conditions described in the Materials and methods section. By this technique it was possible to label the protein with $0.8 \mathrm{~mol}$ equivalent of the reagent. The protein was subsequently subjected to reductive carboxymethylation and digestion by both trypsin and V8 protease as described in the Materials and methods section. Reverse-phase h.p.l.c. $\left(C_{8}\right.$ column, $\left.4.6 \mathrm{~mm} \times 25 \mathrm{~mm}\right)$ resolved the radiolabelled peptides into five separate peaks (Fig. 4). These peaks were individually collected, counted for radioactivity, and dried in vacuo before being re-applied to further purification by reverse phase chromatography using a $\mathrm{C}_{18}$ column and an isocratic gradient (see the Materials and methods section). These five peaks were labelled $f, g, h, i$ and $j$, and each was resolved into peptides, one of which in each case proved to be radioactively labelled. Table 3 gives the details of the percentage of acetonitrile 
Table 2. Sequencing of $\left[{ }^{3} \mathrm{H}\right]$ IAA-labelled peptides from tryptic/V8 digest

The sequence of radiolabelled peptides generated by carboxymethylation of inositol monophosphatase with $\left[{ }^{3} \mathrm{H}\right] \mathrm{IAA}$ followed by trypsin/V8-protease digestion. The percentage of acetonitrile required to elute each peptide, the amount and relative percentage of label associated with each and the percentage yield of each peptide are shown. Superscript CM denotes carboxymethylated. Peaks are the same as those shown in Fig. 3.

\begin{tabular}{|c|c|c|c|c|c|}
\hline \multirow[b]{2}{*}{ Peak } & \multirow{2}{*}{$\begin{array}{c}\text { [Acetonitrile] } \\
\text { for elution }(\%)\end{array}$} & \multicolumn{2}{|c|}{${ }^{3} \mathrm{H}$ associated } & \multirow[b]{2}{*}{ Peptide sequence } & \multirow{2}{*}{$\begin{array}{l}\text { Yield } \\
(\%)\end{array}$} \\
\hline & & (d.p.m.) & $(\%)$ & & \\
\hline a & 21 & 12192 & 34 & GAFC $^{\mathrm{CM}} \mathrm{NGQK}$ & 12.5 \\
\hline b & 32.5 & 4364 & 12 & C $^{\mathrm{CM}}$ LPIHGIR & 28.5 \\
\hline c & 34 & 3119 & 9 & EKYPSHSF & 19.8 \\
\hline d & 38 & 7142 & 20 & LC ${ }^{\mathrm{CM}}$ LPIHGIR & 15.6 \\
\hline e & 41 & 9167 & 25 & LLC $^{\mathrm{CM}}$ LPIHGIR & 10.7 \\
\hline
\end{tabular}

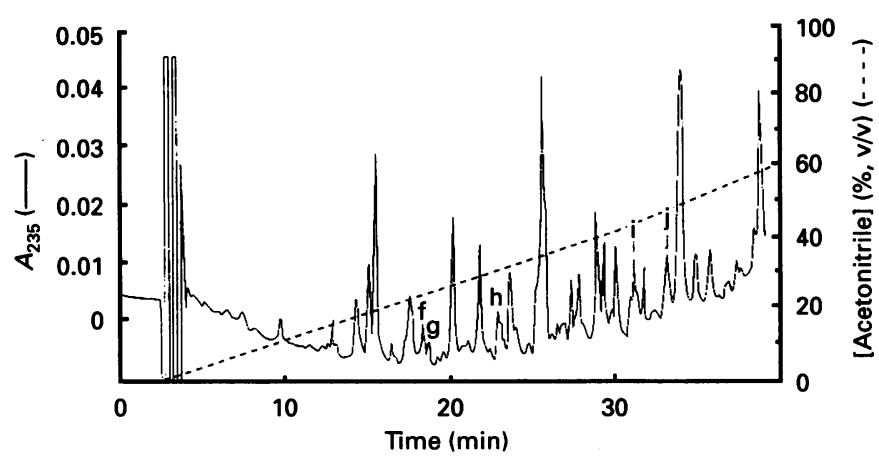

Fig. 4. Elution profile of tryptic/V8 peptides from $\left[{ }^{14} \mathrm{C}\right] \mathrm{NEM}$-modified inositol monophosphatase on a $C_{8}$ reverse-phase column

Reverse-phase h.p.l.c. separation of peptides was performed on $\mathrm{a}_{8}$ column with a solvent gradient formed from $0.1 \%$ TFA in water and $0.1 \%$ TFA in acetonitrile. The flow rate was $1 \mathrm{ml} / \mathrm{min}$ and the gradient run from 0 to $40 \%$ acetonitrile over $30 \mathrm{~min}$ and then to $60 \%$ over a further $10 \mathrm{~min}$. The Figure shows the elution profile obtained when $200 \mu \mathrm{l}$ of $\left[{ }^{14} \mathrm{C}\right] \mathrm{NEM}$-modified enzyme digest is applied and the same solvent gradient used. Peaks $f-j$ contained ${ }^{14} \mathrm{C}$ labelled peptides.

\section{Table 3. Sequencing of $\left({ }^{14} \mathrm{C}\right] \mathrm{NEM}$-labelled peptides}

The sequence of radiolabelled peptides generated by modification of inositol monophosphatase with $\left[{ }^{14} \mathrm{C}\right] \mathrm{NEM}$ followed by trypsin/V8protease digestion. The percentage of acetonitrile required to elute each peptide, the amount and relative percentage of label associated with each is shown.

\section{${ }^{14} \mathrm{C}$ associated}

Peak for elution (\%) (d.p.m.) (\%)

\begin{tabular}{llrrl}
\hline f & 25 & 2994 & 7 & GAFCN \\
g & 26 & 4132 & 9 & No identifiable sequence \\
h & 28 & 11029 & 24 & GAFCNGQK \\
i & 42.5 & 4164 & 9 & No identifiable sequence \\
j & 46 & 23105 & 51 & LLCLPIR
\end{tabular}

for elution, the radioactivity recovered and the sequences of the peptides. Peptides $f$ and $h$ contain $31 \%$ of the radiolabel and both contain only one reactive residue, Cys-141. Peptide $j$ contains $51 \%$ of the radiolabel and represents the linear sequence

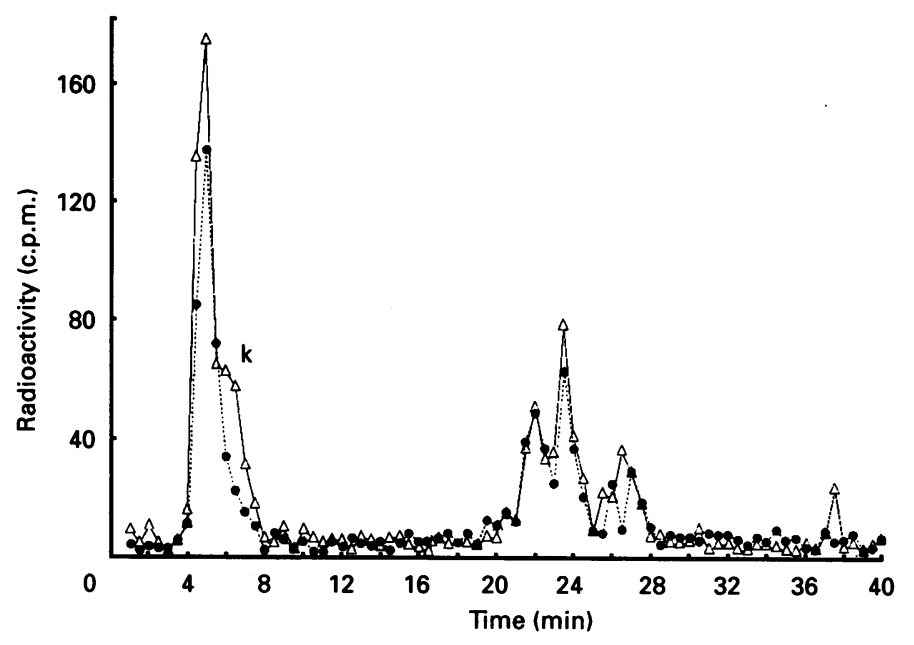

Fig. 5. Elution of $\left.\left.\right|^{14} \mathrm{C}\right] N E M$ treated peptides from h.p.l.c. ion-exchange column chromatography

The Figure shows the elution profiles of radioactive peptides (c.p.m.) released from V8-protease-treated enzyme previously reacted with $1 \mathrm{mM}-\left[{ }^{14} \mathrm{C}\right] N E M$ in the absence $(\triangle)$ or presence $(O)$ of $10 \mathrm{mM}$-Ins $1 P$ and $\mathrm{Li}^{+}$. For details of the experimental procedures and gradient details see the Materials and methods section.

from residue 182 to 191 containing Cys-184. Although the derivative of the cysteine complex is labile under the conditions used in the pulsed liquid sequencer, which prevents a positive assignment to the position of the radiolabel, there was no carboxymethylcysteine present, either. Since the NEM-treated enzyme was reductively carboxymethylated under denaturing conditions after modification by NEM, any available cysteines would have been converted into their carboxymethyl derivative, which is stable under the conditions of the sequencer.

The cysteine at or near to the active site of the enzyme was identified by a difference-labelling technique, i.e. protein samples were labelled in the absence and presence of the substrate and $\mathrm{Li}^{+}$, followed by digestion by $\mathrm{V} 8$ protease alone. Initial peptide analysis was carried out on an ion-exchange h.p.l.c. system. Comparison of the protected and non-protected radiolabelledpeptide elution profiles (monitored at $214 \mathrm{~nm}$ ) showed there to be one additional peak $(k)$, appearing as a trailing shoulder ( $7 \mathrm{~min}$ ) on the first-eluted peak of radioactivity, in the nonprotected sample (see Fig. 5). This peak was isolated, dried in vacuo and further purified on a reverse-phase $\mathrm{C}_{18}$ column, from which a single radioactive peak was eluted in $35 \%$ acetonitrile, peak $m$ (Fig. 6). Fig. 6 shows the elution pattern of radioactivity from samples of enzyme unprotected or protected by Ins $1 P$ and $\mathrm{Li}^{+}$from radiolabelling by NEM. The radioactivity eluted after $185 \mathrm{~min}$ is only present in the sample derived from unprotected enzyme, and this corresponds to the elution of peak $m$ detected by absorption at $235 \mathrm{~nm}$. This peptide was sequenced and corresponded to the peptide MGIHCWDVAG representing the ten residues 214-223 in the linear sequence. Cycle 5 of the sequencing and analytical procedure failed to yield or elute a stable PTH derivative [typical of $S$-( $N$-ethylsuccinimido)cysteine]; however, comparison with the sequence derived from DNA studies [10] confirmed that the expected residue at this position is Cys-218.

\section{Protein fluorescence}

The reaction of the enzyme with NEM could also be monitored by a change in protein fluorescence which occurs on modification by this reagent. Modification of the enzyme by NEM produced 

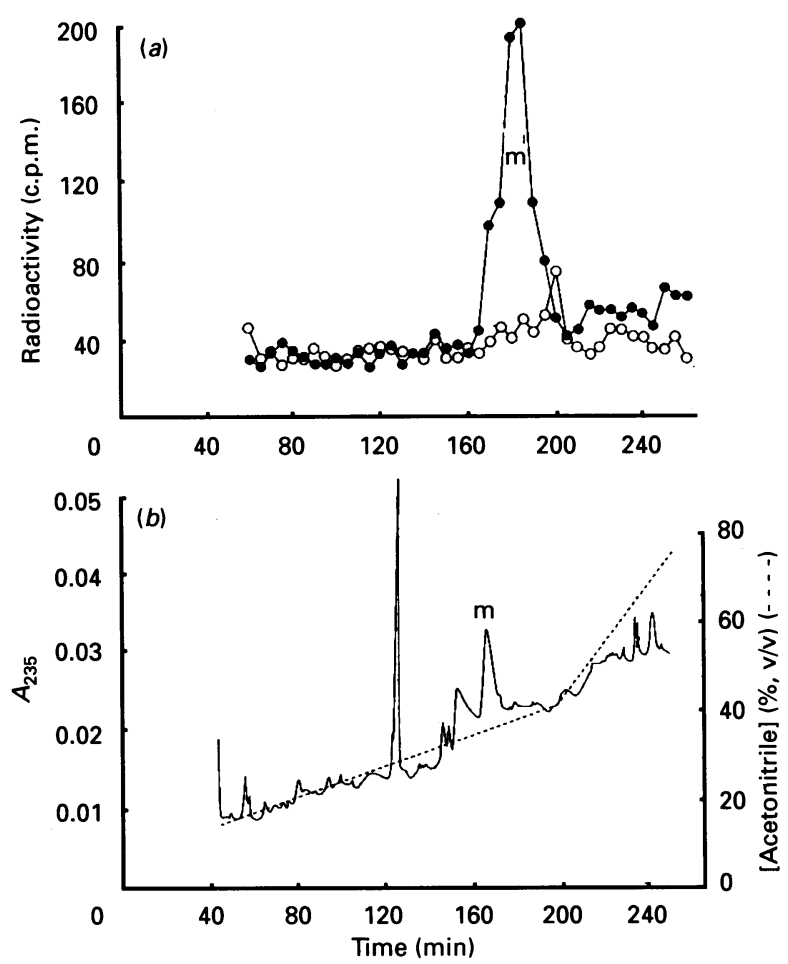

Fig. 6. Purification by reverse-phase $\left(C_{18}\right)$ column chromatography of the ${ }^{14} \mathrm{C}$-labelled peptides (peak $\mathrm{k}$ ) present in the digest derived from unprotected enzyme

The Figure shows the elution profile of radioactivity (c.p.m.) and peptides detected by $A_{235}$ from a reverse-phase $\mathrm{C}_{18}$ column with a water/acetonitrile gradient system (see the Materials and methods section). The samples applied to the column were taken from peak $\mathrm{k}$ eluted from the ion-exchange column described in Fig. 3. The two radioactivity profiles $(a)$ show the elution of radioactivity when peak $\mathrm{k}$ derived from digestion of unprotected $(O)$ and protected $(O)$ enzyme was subjected to separation on this column. The profile describing the elution of peptides detected by the $A_{235}(b)$ is for the sample from unprotected enzyme only.

a $15 \%$ decrease in the fluorescence intensity of the protein (Fig. 7); this change occurs at the same rate (results not shown) as the loss of activity, suggesting that the two phenomena result from the same modification reaction. As was noted when monitoring NEM-induced loss of enzyme activity, the presence of $10 \mathrm{mM}$ $\mathrm{LiCl}$ or $-\mathrm{NaCl}$ (control) has no effect on the rate of decrease of protein fluorescence, whereas $10 \mathrm{~mm}$-Ins $1 P$ decreased the rate of fluorescence change associated with loss of activity. The additional presence of $10 \mathrm{~mm}-\mathrm{LiCl}$ enhanced the protection afforded by substrate from modification with NEM, although a small loss of fluorescence still occurred.

An anomalous situation occurred when the modification was attempted in the presence of $10 \mathrm{~mm}$-phosphate ions (present as $\mathrm{K}_{2} \mathrm{HPO}_{4}$ ). Although phosphate ions have no protective effect on the loss of activity of the enzyme, their presence prevented the changes in protein fluorescence which occurs on modification of the enzyme by NEM. Addition of phosphate ions to enzyme alone caused a small decrease of $2-3 \%$ in protein fluorescence. This small change in protein fluorescence was a $\mathbf{M g}^{2+}$-dependent process, as was the phosphate protection of fluorescence quenching by NEM.

\section{Effect of mutating Cys-218 to Ala-218}

The positive assignment of the NEM-reactive residue in or near to the active site of the enzyme was confirmed by experiments using a mutant enzyme where Cys-218 has been replaced by an

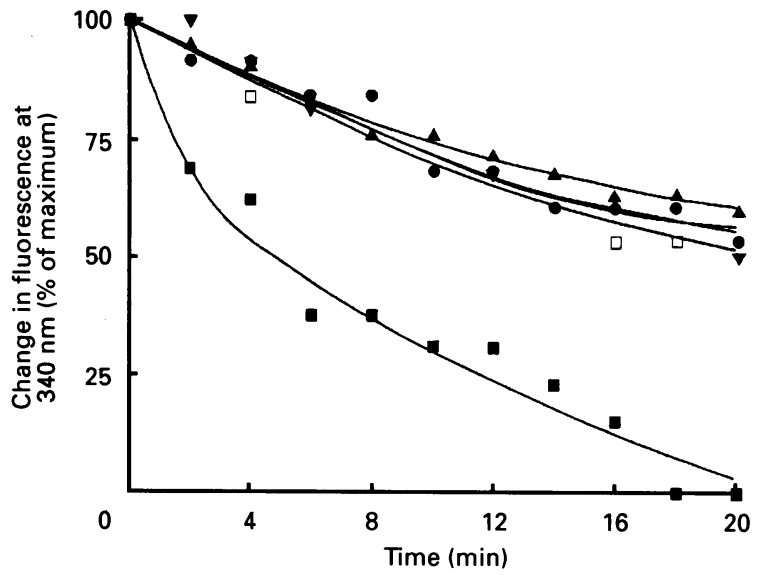

Fig. 7. Change in protein fluorescence of inositol monophosphatase on reaction with NEM

The Figure shows the effect of incubation with $1 \mathrm{mM}-\mathrm{NEM}$ on the fluorescence intensity of native enzyme, with $(\nabla)$ or without $10 \mathrm{mM}$ Ins $1 P$ and $10 \mathrm{mM}^{-\mathrm{Li}^{+}}(\square)$ and mutant enzyme with $(\square)$ or without (O) Ins $1 P$ and $\mathrm{Li}^{+}$(each $10 \mathrm{mM}$ ), or with $10 \mathrm{~mm}$-phosphate $(\triangle)$. The fluorescence of the protein was excited at $280 \mathrm{~nm}$ and the emitted light monitored at $340 \mathrm{~nm}$.

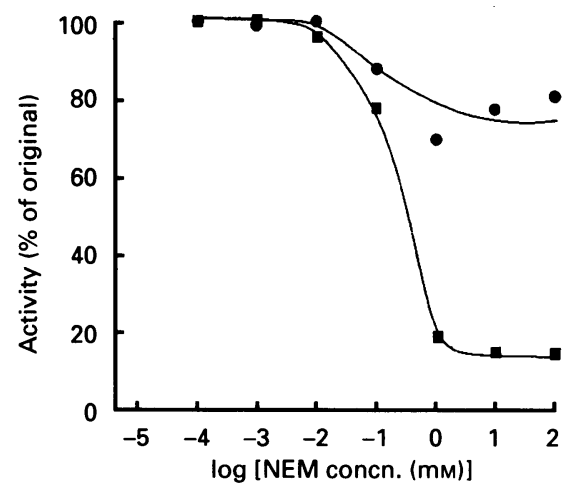

Fig. 8. Reaction of NEM with native or a Cys-218 $\rightarrow$ Ala mutant of inositol monophosphatase

The Figure shows the effect of incubation with NEM on the activity of the native ( $\square$ ) or mutant enzyme (@).

alanine residue. This mutant was found to be fully active, having $156 \%$ of the catalytic activity of the native enzyme (max. specific activity $=21.2 \mu \mathrm{mol} / \mathrm{min}$ per $\mathrm{mg})$ and a $K_{\mathrm{m}}(93 \mu \mathrm{M})$ for the substrate approximately equal to that of the native protein $(103 \mu \mathrm{M})$. These unexpected observations establish conclusively that Cys-218 is not essential for catalytic activity or for substrate binding to occur. This mutated enzyme was not inhibited by incubation with $1 \mathrm{mM}-\mathrm{NEM}$ and only inactivated by approx. $20 \%$ by reaction with $10 \mathrm{~mm}-\mathrm{NEM}$ (Fig. 8). Although incubation with NEM failed to inactivate the enzyme significantly, $1 \mathrm{~mol}$ equivalent of $\left[{ }^{14} \mathrm{C}\right] N E M$ was incorporated into the enzyme. Furthermore, in the presence of this reagent, the fluorescence emission from the mutant protein showed no greater change than the native enzyme totally protected by the presence of substrate and $\mathrm{Li}^{+}$(Fig. 7).

\section{DISCUSSION}

The bovine inositol monophosphatase is inactivated by chemical modification by NEM and DTNB. Two equivalents of DTNB per monomer are able to react with the native protein, 
although all six cysteines per monomer can react when the protein is denatured in SDS, indicating that there are no disulphide bridges in the protein. The protein displays differential reactivity to thiol reagents. The residue reactive to haloacetates is not located in the active site, since the modified enzyme retains full activity. The slight increase in activity may be due to the modification of the other residue(s) that are reactive to DTNB and NEM, giving rise to a change in the enzyme conformation that results in enhancement of activity. The discrimination shown by the sites reactive to DTNB and NEM against haloacetates may arise as a result of the residue being located in an anionic environment or may be due to other steric influences.

The fact that Ins1 $P$ protects the enzyme from inactivation, whereas the phosphate ion does not, suggests either that the substrate induces a conformation not attainable by the $\mathrm{P}_{\mathrm{i}}$-enzyme complex and not reactive to NEM, or that the site of modification by the reagent is protected by the inositol moiety. Unfortunately, myo-inositol fails to act as a competitive inhibitor even at very high concentrations [4], and therefore we were unable to test the latter hypothesis. The equally high protection given by the inhibitor $(1 S)$-phosphoryloxy- $(2 R, 4 S)$-dihydroxycyclohexane is almost certainly due to the low dissociation constant for this compound and also to its decreased rate of dephosphorylation compared with the true substrates.

Chemical modification of amino acid residues in enzymes is a recognized technique used to locate and identify amino acid residues in or near to the active site of enzymes. The sequence information has shown that the incorporation of the single molecule of IAA results from the modification of two different thiol residues (Table 2), each of which is half-modified by the reagent. The two modified thiol groups were found to be in residues Cys-141 and -184; these residues were found to show similar half-reactions with NEM (Table 3). This pattern of modification may arise for a number of different reasons. Firstly, the two residues concerned, Cys-141 and -184 , may react in a mutually exclusive manner, i.e. modification of one residue by the reagent sterically hinders the modification of the other. Alternatively, the modification of Cys-141 or -184 in one subunit may prevent the modification of the same residue in the other subunit of the dimer. Since the incorporation of radioactivity is approximately equal, the two thiol groups must be of similar overall reactivity. The steric hindrance to the modification of the second group is not due to the charged nature of IAA, since the same pattern of labelling was obtained with NEM. The possibility of a conformation change after the modification of either Cys141 or -184 which results in inhibition of the reaction of the other with the reagents seems improbable, since the enzyme is still fully active. Finally the possibility that a proportion of these two residues, e.g. half of them, are inter-bonded via a disulphide bridge and are therefore unavailable for reaction is equally remote, since under denaturing but non-reductive conditions it is possible for all six cysteine residues to react with DTNB. In other enzymes, two cysteine residues not involved in a disulphide bridge in the native enzyme have still been close enough to each other to permit a disulphide-interchange reaction between one of them and the other modified by a NTB ${ }^{2-}$ group from DTNB [26], thus leading to the formation of a disulphide bridge in the modified species. This is not the case with inositol monophosphatase, since only 2 mol equivalents of $\mathrm{NTB}^{2-}$ are released from reaction with DTNB. It seems most probable that the $2 \mathrm{~mol}$ equivalents of $\mathrm{NTB}^{2-}$ released by reaction of the enzyme with DTNB are in fact due to reaction at the same three residues as NEM. Mutagenesis studies have clearly demonstrated that Cys218 is not an essential residue for catalytic activity. The mutant has a similar $K_{m}$ and an increased $V_{\max }$. relative to the native enzyme. Inositol monophosphatase contains three tryptophan residues, numbered 5, 87 and 219 in the linear sequence [9]. The sensitivity of tryptophan fluorescence to changes in protein conformation or microenvironment has been widely reported [27-29]. The perturbation in fluorescence intensity of inositol monophosphatase on modification with NEM must therefore reflect such changes. The results obtained by monitoring protein fluorescence fully support the kinetic data, with one exception. Whereas phosphate prevents the change in fluorescence intensity, it offers no protection against loss of enzyme activity. Since phosphate induces a small decrease in fluorescence intensity in the presence of $\mathrm{Mg}^{2+}$ (not observed in the absence of the cation), it is possible that the environment of the reporting tryptophan residue(s) is altered and not sensitive to changes normally caused by reaction of the enzyme with NEM. The requirement for the presence of $\mathrm{Mg}^{2+}$ for the phosphate effect suggests that phosphate binding requires the presence of this metal. This is in agreement with another report [30], which noted that phosphate protection of the modification of an arginine residue by phenylglyoxal is $\mathrm{Mg}^{2+}$-dependent. When the enzyme is almost totally protected from inactivation by NEM, by the presence of Ins $1 P$ and $\mathrm{Li}^{+}$, a small decrease in fluorescence intensity was still noted. This must arise from modification of the enzyme at the second, NEMsensitive, non-active-site residue. The mutant Cys-218 to Ala-218 shows a similar change in fluorescence intensity in the presence of NEM to the native protein when modification of the activesite region (and Cys-218) is protected by the substrate and $\mathrm{Li}^{+}$, thus implicating the quenched tryptophan as Trp-219 (Fig. 7). The small amount of fluorescence quenching that does occur in this mutant and in the native protein in the presence of substrate and $\mathrm{Li}^{+}$must result from modification of Cys-141 and/or Cys184. The effect of phosphate is the same in the native enzyme and the Cys-218 $\rightarrow$ Ala mutant. Phosphate does not protect the enzyme from inactivation by NEM, but appears to prevent the quenching of fluorescence which occurs on modification of Cys218. In conclusion, these studies have demonstrated that Cys- 218 resides at or near to the active site of inositol monophosphatase, and its modification by NEM sterically or conformationally hinders the binding of substrate or the catalytic processes, rather than removing an essential component of the catalytic mechanism.

M.G.G. is indebted to the S.E.R.C. Molecular Recognition Initiative for the provision of the ABI 477A sequencer and to the S.E.R.C. and M.S.D. for the studentship for P.J.G.

\section{REFERENCES}

1. Shears, S. B. (1989) Biochem. J. 260, 313-324

2. Downes, C. P. \& Michell, R. H. (1985) in Molecular Mechanisms of Transmembrane Signalling (Cohen, P. \& Houslay, M. D., eds.), pp. 3-56, Elsevier, Amsterdam

3. Abdel-Latif, A. A. (1986) Pharmacol. Rev. 38, 227-272

4. Gee, N. S., Ragan, C. I., Watling, K. J., Aspley, S., Jackson, R. G., Reid, G. R., Gani, D. \& Shute, J. K. (1988) Biochem. J. 249, 883-889

5. Eisenberg, F. Jr. (1967) J. Mol. Chem. 242, 1375-1382

6. Hallcher, L. M. \& Sherman, W. R. (1980) J. Biol. Chem. 255, 10896-10901

7. Shute, J. K., Baker, R., Billington, D. C. \& Gani, D. (1988) J. Chem. Soc. Chem. Commun. 626-628

8. Berridge, M. J., Downes, C. P. \& Hanley, M. R. (1989) Cell 59, 411-419

9. Diehl, R. E., Whiting, P., Potter, J., Gee, N. S., Ragan, C. I., Linemeyer, D., Schoepfer, R., Bennett, C. \& Dixon, R. A. (1990) J. Biol. Chem. 265, 5946-5954

10. Ganzhorn, A. J. \& Chanal, M. C. (1990) Biochemistry 29, 6065-6071

11. Means, G. E. \& Feeney, R. E. (1971) Chemical Modification of Proteins, Holden-Day, Oakland

12. Torchinsky, Y. M. (1981). Sulphur in Proteins, Pergamon Press, Oxford

13. Gregory, J. D. (1955) J. Am. Chem. Soc. 77, 3922-3927

14. Ellman, G. L. (1959) Arch. Biochem. Biophys. 82, 70-77 
15. Rapkine, L. (1937) C. R. Soc. Biol. 112, 790-793

16. McAllister, G., Whiting, P. J., Hammond, E. A., Knowles, M. R., Atack, J. R., Bailey, F. J., Maigetler, R. \& Ragan, C. I. (1992) Biochem. J. 284, 749-754

17. Billington, D. C., Baker, R., Kulagowski, J. J. \& Mawer, I. M. (1987) J. Chem. Soc., Chem. Commun. 314-316

18. Baker, R., Leeson, P. D., Liverton, N. J. \& Kulagowski, J. J. (1990) J. Chem. Soc. Chem. Commun. 462-464

19. Ragan, C. I., Watling, K. J., Gee, N. S., Aspley, S., Jackson, R. G., Reid, G. G., Baker, R., Billington, D. C., Barnaby, R. J. \& Leeson, P. D. (1988) Biochem. J. 249, 143-148

20. De Groot, H., De Groot, H. \& Noll, T. (1985) Biochem. J. 229, 255-260

21. Lanzetta, P. A., Alvarez, L. J., Reinach, P. S. \& Candia, O. A. (1979) Anal. Biochem. 100, 95-97
22. Bradford, M. M. (1976) Anal. Biochem. 72, 248-254

23. Kunkel, T. A. (1985) Proc. Natl. Acad. Sci. U.S.A. 82, 488492

24. Kunkel, T. A., Roberts, J. D. \& Zakour, R. A. (1987) Methods Enzymol. 154, 367-382

25. Sanger, F., Nicklen, S. \& Coulson, A. R. (1977) Proc. Natl. Acad. Sci. U.S.A. 74, 5463-5467

26. Flashner, M., Hollenberg, P. F. \& Coon, M. J. (1972) J. Biol. Chem. 247, 8114-8121

27. Ashby, B., Wooton, J. C. \& Finchorn, J. R. S. (1974) Biochem. J. 143, 317-329

28. Timasheff, S. N. (1970) Enzymes 3rd Ed. 2, 417-430

29. Cowgill, R. W. (1965) Biochim. Biophys. Acta 94, 81-88

30. Jackson, R. G., Gee, N. S. \& Ragan, C. I. (1989) Biochem. J. 264, $419-422$

Received 17 October 1991/20 January 1992; accepted 5 February 1992 